\title{
Online Support Services in e-Learning: A Technology Acceptance Model
}

\author{
Hina Saeed* $\quad$ Moiz uddin Ahmed* $\quad$ Shahid Hussain ${ }^{\dagger} \quad$ Shahid Farid $^{\ddagger}$
}

\begin{abstract}
The development in the Information and Communication Technology in the contemporary digital age is rapidly changing the dynamics of the communication industry. The integration of technology in education is especially open and distance learning sector has given rise to e-leaning, which is the technology driven mode of education. Due to this emerging nature of the phenomenon, the students' ability to accept and respond to online support services is important for the success of e-learning system. This paper investigates the attitude of the students towards online support services at the Allama Iqbal Open University (AIOU), Pakistan, using Technology Acceptance Model. The AIOU is the second largest distance learning institute of the world. A questionnaire was adopted and customized from the previous studies to collect the feedback from the students. The feedback from 220 students was collected using the said questionnaire. The statistical techniques using the descriptive statistics and linear regression were applied to analyze the data. The results show a positive attitude of students towards the online support services. The regression analysis elaborates that there is a significant influence of the "perceived usefulness" of online support services on "behavioral intention". Furthermore, the regression analysis shows a significant influence of the "ease of use" on "behavioral intention".
\end{abstract}

Keywords: Technology Acceptance Model (TAM), E-learning, "Ease of use", "Perceived Usefulness"

\section{Introduction}

E-learning is the process of teaching via computers, the Internet and media technologies. It includes computer software based training, World Wide Web-based learning and broadcast media based learning [1]. The electronic mode uses Information and Communication Technology (ICT) to deliver the instructions [2]. These instructions are digitized using audio, video and multimedia technologies. The e-learning has become the need of learners of the present age. However, new issues are arising because technology is changing rapidly, affecting every field of life [3]. New models of e-learning are needed that can engage learners by catering their needs and styles of e-learning [4] through effective online support services.

The online support services deliver the course instructions by using web portals and Learning Management Systems (LMS). LMS is a specially designed application which provides a platform for executing online support services to distant learners [5]. The course instructions can be uploaded by the instructors that can be downloaded by the students, anywhere and anytime. The communication can also be established by using synchronous and asynchronous mode of instructions [5]. The synchronous mode is the real-time interaction in which students, as well as teachers, are present. Audio/Video conferencing and chat discussions are the synchronous forms of communication. Asynchronous is offline communication between teachers and students in the form of email, and forums, etc. [6]. Both synchronous and asynchronous interactions are the basic building block of communication in an e-learning system; however; a successful online system requires acceptance of emerging tools and technologies by the relevant users. The success of any technologybased service is dependent on its acceptance which can be measured by employing the technology acceptance models and framework that analyze users' intention of using new systems and applications. The important models of technology acceptance as reported in the literature review are Unified Theory of Acceptance, and Use of Technology (UTAUT), Diffusion of Innovation (DOI), and Technology Acceptance Model (TAM) [vii]. The TAM has been widely used to find user acceptance,

\footnotetext{
${ }^{*}$ Department of Computer Science, Allama Iqbal Open University, Islamabad

${ }^{\dagger}$ Department of Mass Communication, Allama Iqbal Open University, Islamabad

$\ddagger_{\text {Department of Computer Science, BZU, Multan }}$

Corresponding Email: hinas1817@gmail.com
} 
willingness, attitude, behavioral intention about the new technology and online support services which are affected indirectly by the perception of usefulness and ease. Keeping importance of technology transformation in view and implementation of e-learning this paper analyzes personal beliefs of "Perceived Usefulness" (PU), "Perceived Ease of Use" (EOU) and "Behavioral Intentions" (BI) about online support services in e-learning initiated at AIOU, Pakistan.

\section{Related Work}

TAM has come out from the Theory of Reasoned Action (TRA) about human behavior [7]. It deals with the level of acceptance of Information Systems by analyzing the behavior and intentions of concerned users [8]. The Davis defines EOU as a degree of belief according to which a user will not be scared of any physical exertion while using a new technology system. The PU is conceptualized as a degree of belief according to which a user will be able to enhance his/her performance while using a new system [8]. Both the parameters are the basic building block of TAM theory and can predict the attitude of individuals towards using a new system. The attitude affects the "Behavioral intention" (BI) towards using a new system or application [9].

In the case of e-learning, the likelihood of using the support services depends upon the attitude of students towards computer-based systems [10]. It implies that if the online system is user-friendly and easy to operate, it may result in increasing the interaction level [11]. There is a number of external variables that can be used with TAM to investigate the learner's intention towards e-learning system [12]. The important variables include personal profiles of learners, organizational parameters, characteristics of e-learning systems and access to ICT devices. These variables influence PU though EOU depending upon the degree of beliefs that impress the learner's decision towards online support services provided. The user interface of LMS and web portals can play an important role to strengthen the Human-Computer Interaction (HCI).

The study of [13] highlighted that organizational policies, training of using online systems and interface are important in the adoption of LMS in the higher education institutes. The study investigated the effect of social networking, performance \& effort expectancy and infrastructure towards the acceptance of LMS in the higher institutes in Kenya. The research described in [14] has analyzed the "behavioral intention" of students towards using e-learning applications. The study revealed that self-efficacy is the most important motivational factor towards e-learning "behavioral intention". The study [15] reviewed the acceptance of e-learning in developing countries. The study showed that social factors and motivation have a strong impact on intention towards the usage of e-learning systems.
The research [16] evaluated the parameters that influence the acceptance and usage of e-learning in educational institutes of New Zealand. The results highlighted that personal profiles and organizational parameters are both important towards the adoption of learning online. The research [17] evaluated students' attitude in relation to TAM while using e-learning. The study found that attitude has a substantial role in e-learning acceptance among students enrolled in University in Malaysia. The regional characteristics in terms of localized parameters are also found as an important factor in its acceptance. The acceptance level will be increased if the learning system will be developed after considering its user's local learning needs and requirement.

It is concluded that the rapid developments and expansion in modern technology has posed many challenges regarding its acceptance among potential users [18]. Different theories and models have come up to analyze user behaviors. TAM is more important as it has widely been used to analyze the student's feedback in many technologies enable learning paradigm. The previous studies have shown strong empirical results to prove the validity of TAM. Social media is also one of the areas which have been explored to study the learning impact on student's behavior using TAM [19]. The systematic literature view has also concluded to use the TAM in new learning dimensions [20].

\section{Proposed Model}

The three online support services are selected to find their "perceived usefulness" and "ease of use" for encouraging students' "behavioral intention".

A. Quality of Digital Contents

Digital Contents are an important part of an elearning system. The digital contents comprise course tutorials, assignment, activities, questions, FAQS and announcements etc. Due to the geographical distance between students and teachers the quality of digital contents is very important. These contents must match with the course objectives and the learning outcomes. The content may effectively contribute to self-paced learning of the students if it conforms to the quality standards.

B. Uploading and Downloading of Contents There are heterogeneous Internet connections available to students. These connections are dependent upon various parameters like efficiency, reliability, user-friendly interface, and error handling. Any complexity in the process may confuse the students [21]. A student requires seamless and error-free services for downloading the digital contents. Therefore, the "behavioral intention" is related to "ease of use" and "usefulness" of uploading/downloading.

C. Asynchronous/synchronous interaction The synchronous and asynchronous interaction pro- 
vides a communication mechanism between teachers and students and services departments like admission, examination, etc. The communication should be reliable and fast for the prompt reply to the distant students. If synchronous and asynchronous interaction meets the students' expectations, it may result in increasing the degree of belief of "ease of use" and "perceived usefulness" and motivation.

\section{Proposed Hypothesis}

The high degrees of $\mathrm{PU}$ and EOU can result in more confidence of students towards online support services while participating in e-learning activities [22]. This study, therefore, considered the important parameters reported in the literature review for the formulation of the research hypothesis. The statement form of the hypotheses are given below and the symbolic form is shown in figure 1.

[H1] Uploading and downloading of digital contents will have a significant influence on "perceived usefulness" of online support services.

[H2] Uploading and downloading of digital contents will have a significant influence on "ease of use" of online support services. [H3] The quality of digital contents will have a significant influence on "perceived usefulness" of online support services.

[H4] The quality of digital contents will have a significant effect on "ease of use" of online support services.

[H5] The asynchronous and synchronous interaction will have a positive influence on "perceived usefulness" of online support services.

[H6] The asynchronous and synchronous interaction will have a positive influence on "perceived ease of use" of online support services.

[H7] The "perceived ease of use" will have a positive influence on "perceived usefulness" of online support services.

[H8] The "perceived usefulness" will have a positive influence on "behavioral intention" of using online support services.

[H9] The "perceived ease of use" will have a positive influence on "behavioral intention" of using online support services.

\section{Research Methodology}

A. Sample

A survey was conducted from the students of AIOU,
Pakistan to evaluate the application of TAM on online support services. The AIOU is the second largest open university of the world in terms of number of students. The university is in the transformation phase of converting distance learning programs into modern e-learning based mode [23].

The survey was distributed to Computer Science students studying at AIOU. It was comprised of questions about online support services on 5 - Point Likert scale. These questions were developed on the basis of e-learning initiatives taken at AIOU [23] and previous research of analyzing information systems using TAM [24-27].

The final questionnaire was comprised of 23 items to measure the six constructs Digital Content Quality (DCQ), Uploading/Downloading UD, Asynchronous/ Synchronous Interaction (ASI), "Perceived Usefulness" (PU), "Perceived Ease of Use" (EOU), "Behavioral Intention to use" (BI). The survey questionnaire also comprised the demographic items that indicated the age, gender, employment and accessibility to computer \& Internet. The convenience sampling technique was used to collect feedback from the target population.

\section{B. Data Analysis}

The data collected with the help of questionnaire has been analyzed quantitatively. The demographics results are shown in Table 1. It shows that males are $80 \%$ and females $20 \%$. The age of respondents ranged from 1520 to $30+$, however majority of the respondents belongs to $26-30$ age group. The majority $(59.1 \%)$ are engaged in jobs. PCs with Internet connections are also available to a large majority of respondents.

Table 1: Demographics

\begin{tabular}{|l|c|c|}
\hline Variable & Frequency & Percentage \\
\hline Gender & & \\
\hline Male & 176 & $80 \%$ \\
\hline Female & 44 & $20 \%$ \\
\hline Age Group & & \\
\hline $15-20$ & 57 & $25.9 \%$ \\
\hline $21-25$ & 26 & $11.8 \%$ \\
\hline $25-30$ & 73 & $33.2 \%$ \\
\hline $30+$ & 64 & $29.1 \%$ \\
\hline In service & & \\
\hline Employed & 130 & $59.1 \%$ \\
\hline Non-employed & 90 & $40.9 \%$ \\
\hline Personal Computer & & \\
\hline Yes & 220 & $100 \%$ \\
\hline No & 0 & Nil \\
\hline Internet Facility & & \\
\hline Yes & 211 & $95.9 \%$ \\
\hline No & 9 & $4.1 \%$ \\
\hline
\end{tabular}

\section{Descriptive Statistics}

The Descriptive statistics of six variables can be seen in Table 2. The mean value is high i.e. closer to 4 which indicate the influence of variables on acceptance of online support services. The SD values are approximately 
equal to 1 which indicates small deviations from the mean value.

Table 2: Descriptive Statistics

\begin{tabular}{|l|c|c|}
\hline Variables & Mean & Std. Deviation \\
\hline EOU1 & 4.04 & 0.840 \\
\hline EOU2 & 3.90 & 1.066 \\
\hline EOU3 & 3.87 & 1.061 \\
\hline EOU4 & 3.88 & 1.070 \\
\hline PU1 & 3.93 & 1.074 \\
\hline PU2 & 3.85 & 1.056 \\
\hline PU3 & 3.88 & 1.172 \\
\hline PU4 & 3.93 & 1.042 \\
\hline BI1 & 3.88 & 1.185 \\
\hline BI2 & 3.74 & 1.148 \\
\hline BI3 & 3.77 & 1.054 \\
\hline UD2 & 3.84 & 1.121 \\
\hline UD3 & 3.80 & 1.081 \\
\hline UD4 & 3.75 & 1.087 \\
\hline UD5 & 3.80 & 1.061 \\
\hline DC1 & 3.93 & 0.953 \\
\hline DC2 & 3.93 & 1.002 \\
\hline DC3 & 3.80 & 1.064 \\
\hline DC4 & 3.94 & 0.972 \\
\hline ASI4 & 3.76 & 1.118 \\
\hline ASI5 & 4.06 & 0.894 \\
\hline ASI6 & 3.87 & 1.052 \\
\hline ASI7 & 3.92 & 1.022 \\
\hline & & \\
\hline
\end{tabular}

D. Reliability Measures

The internal reliability and construct validity of the questionnaire were evaluated to determine the stability and suitability of the questions. There are 220 entries of data and for this range of data the factor loading values should be 0.5 least and the Cronbach's alpha range should be between $0.6-0.7,0.8$ is considered as strong reliability between variables while below 0.6 is as weaken. The below table shows that total 23 variables are being used for factor analysis, having 0.825 Cronbach's alpha value for the reliability of these variables that is much efficient to prove that.

Table 3: Cronbach Alpha

\begin{tabular}{|l|l|l|}
\hline $\begin{array}{l}\text { Cronbach's } \\
\text { Alpha }\end{array}$ & $\begin{array}{l}\text { Cronbach's Al- } \\
\text { pha Based on } \\
\text { Standardized } \\
\text { Item }\end{array}$ & No. of Items \\
\hline 0.825 & 0.824 & 23 \\
\hline
\end{tabular}

\section{E. Appropriateness of Data (adequacy)}

The appropriateness and sphericity of data were calculated through KMO and Bartlett's test. Kaiser-Meyer Olkin test value was 0.790 (close to 0.8 ), and therefore, considered as good [28]. The significance value was less than 0.05 that showed the data appropriateness for further factor analysis.

Table 4: KAISER-MEYER-OLKIN (KMO) Measure

\begin{tabular}{|l|l|l|}
\hline KMO Measure of Sampling Adequacy & 0.790 \\
\hline Bartlett's Test of & Approx. & $1.367 \mathrm{E}$ \\
Sphericity & Chi-Square & \\
\cline { 2 - 3 } & Df & 253 \\
\cline { 2 - 3 } & Sig. & 0.000 \\
\hline
\end{tabular}

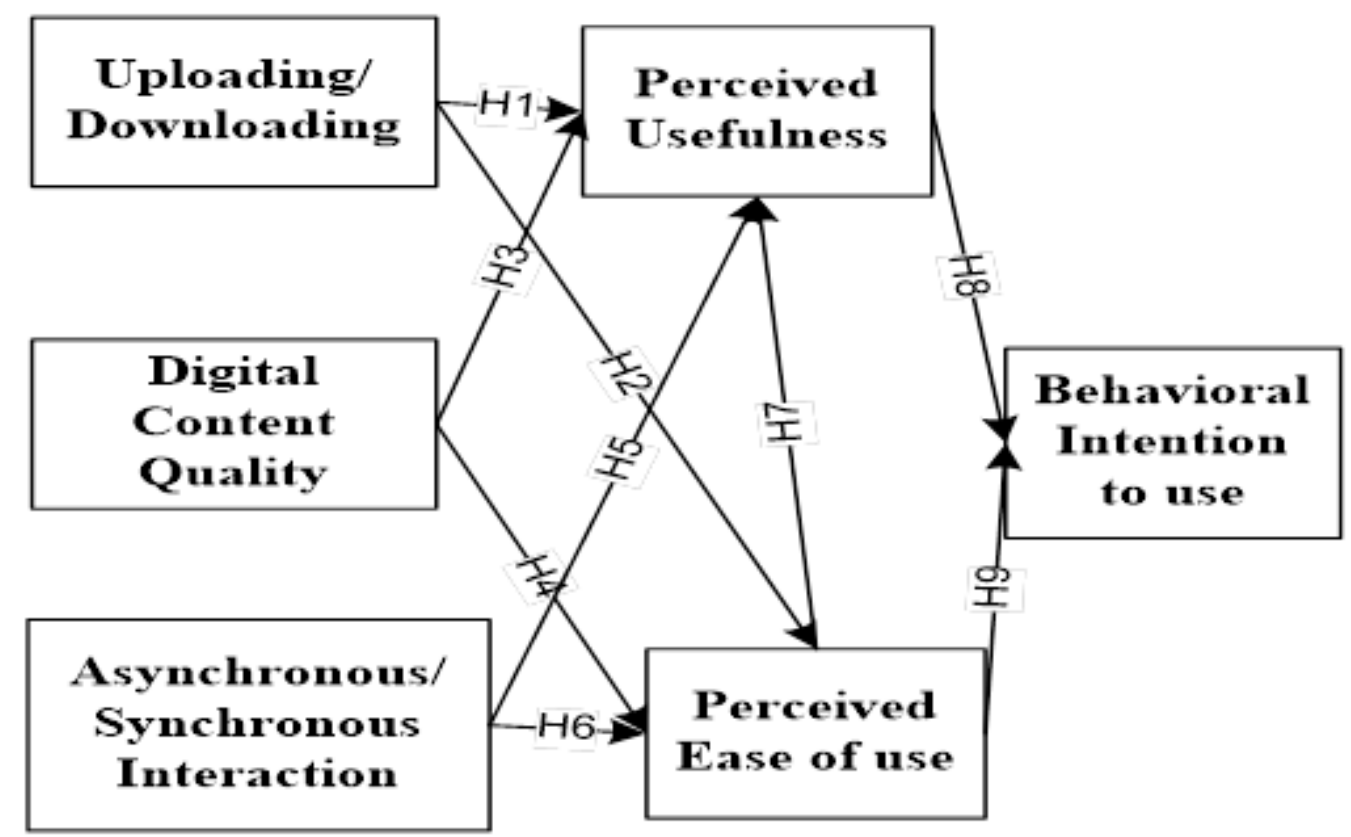

Figure 1: Proposed Model with Hypothesis relation 


\section{F. Factor Loading}

The factor loading matrix is shown below in Table 5 which indicates the relationship of the questions with factors. Higher the loading across the item, stronger is its relationship with the factor [29]. The values are between 0.5 and 0.7 which indicate a strong relationship among the items. The Exploratory Factor Analysis (EFA) was calculated by computing the eigenvalues. The factors with eigenvalues greater than 1 are considered significant and others are discarded on the basis of Kaiser latent root criterion [29]. Six factors with eigenvalues greater than 1 were extracted which resulted in $57 \%$ of the variance.

Table 5: Factor Loading

\begin{tabular}{|l|l|l|l|l|l|}
\hline & 1 & 2 & 3 & 4 & 5 \\
\hline EOU1 & 0.800 & & & & \\
\hline EOU2 & 0.824 & & & & \\
\hline EOU3 & 0.758 & & & & \\
\hline EOU4 & 0.582 & & & & \\
\hline PU1 & & & & & 0.497 \\
\hline PU2 & & & & & 0.530 \\
\hline PU3 & & & & & 0.723 \\
\hline PU4 & & & & & 0.771 \\
\hline BI1 & & & & & \\
\hline BI2 & & & & & \\
\hline BI3 & & & & & \\
\hline UD1 & & 0.646 & & & \\
\hline UD2 & & 0.740 & & & \\
\hline UD3 & & 0.749 & & & \\
\hline UD4 & & 0.686 & & & \\
\hline DC1 & & & 0.566 & & \\
\hline DC2 & & & 0.699 & & \\
\hline DC3 & & & 0.656 & & \\
\hline DC4 & & & 0.715 & & \\
\hline ASI1 & & & & 0.706 & \\
\hline ASI2 & & & & 0.722 & \\
\hline ASI3 & & & & 0.646 & \\
\hline ASI4 & & & & 0.562 & \\
\hline $\begin{array}{l}\text { \%Variance } \\
\text { explained }\end{array}$ & 12.806 & 11.001 & 8.531 & 8.474 & 8.413 \\
\hline $\begin{array}{l}\text { Cumulative } \\
\text { percent- } \\
\text { age }\end{array}$ & 12.806 & 23.807 & 32.337 & 40.811 & 49.224 \\
\hline & & & & \\
\hline
\end{tabular}

\section{Analysis of Proposed Hypothesis}

To test the first hypothesis (H1), the regression analysis was carried out as shown in Table 6 . Table 6 shows that uploading and downloading of contents is positively related to "perceived usefulness". It reveals that strong relationship between online support services and "perceived usefulness". The p-value shows that H1 is supported and accepted.

Table 7 shows that uploading and downloading of contents is positively related to "ease of use". It reveals that strong relationship exists between online support services and "ease of use".

Table 8 shows the regression analysis for H3. The result shows that digital content quality has a significant influence on "perceived usefulness".

Table 9 shows the regression analysis for H4. The result shows that digital content quality (DC) has a significant influence on "ease of use".

Table 10 shows the regression analysis for H5. The result shows that asynchronous and synchronous interaction has a significant influence on "perceived usefulness".

Table 11 shows the regression analysis for H6. The result shows significant influence of asynchronous and synchronous interaction on "perceived ease of use".

Table 12 shows regression analysis for H7. The result shows that there is significant influence of "perceived ease of use" on "perceived usefulness".

Table 13 shows the regression analysis for H8, which elaborates that there is significant influence of "perceived usefulness" of online support services on "behavioral intention".

Table 14 shows the regression analysis for H9. The result shows a significant influence of "ease of use" on "behavioral intention".

The results show that effects are significant and all the hypotheses have been supported. The previous studies have also shown significant effect of EOU on PU and BI $[9,30]$. The students of e-learning have shown positive attitude towards online support services. The "perceived usefulness" has a greater significant correlation with usage behavior than "perceived ease of use". This led to hypothesize that "perceived ease of use" may be a causal predecessor to "perceived usefulness" rather than a direct determinant of technology usage [9]. The positive feelings of the users to "ease of use" are certainly linked with its sustainability [31]. The proposed model with hypothesis results is shown in figure 2 .

Table 6: Regression Result For H1

\begin{tabular}{|l|l|l|l|l|l|}
\hline H1 & B & $\begin{array}{l}\text { Standard- } \\
\text { Error(B) }\end{array}$ & T & P & $\begin{array}{l}\text { R } \\
\text { Square }\end{array}$ \\
\hline $\mathrm{UD} \rightarrow \mathrm{PU}$ & 0.167 & 0.064 & 2.504 & $<0.013$ & 0.028 \\
\hline
\end{tabular}

Table 7: Regression Result For H2

\begin{tabular}{|l|l|l|l|l|l|}
\hline H2 & B & $\begin{array}{l}\text { Standard- } \\
\text { Error(B) }\end{array}$ & T & P & $\begin{array}{l}\text { R } \\
\text { Square }\end{array}$ \\
\hline $\mathrm{UD} \rightarrow$ EOU & 0.205 & 0.067 & 3.091 & $<0.002$ & 0.042 \\
\hline
\end{tabular}

Table 8: Regression Result For H3

\begin{tabular}{|l|l|l|l|l|l|}
\hline H3 & B & $\begin{array}{l}\text { Standard- } \\
\text { Error(B) }\end{array}$ & T & P & $\begin{array}{l}\text { R } \\
\text { Square }\end{array}$ \\
\hline $\mathrm{DC} \rightarrow \mathrm{PU}$ & 0.159 & 0.075 & 2.375 & $<0.018$ & 0.025 \\
\hline
\end{tabular}

Table 9: Regression Result For H4

\begin{tabular}{|l|l|l|l|l|l|}
\hline H4 & B & $\begin{array}{l}\text { Standard- } \\
\text { Error(B) }\end{array}$ & T & P & $\begin{array}{l}\text { R } \\
\text { Square }\end{array}$ \\
\hline $\mathrm{DC} \rightarrow \mathrm{PU}$ & 0.160 & 0.079 & 2.395 & $<0.017$ & 0.026 \\
\hline
\end{tabular}




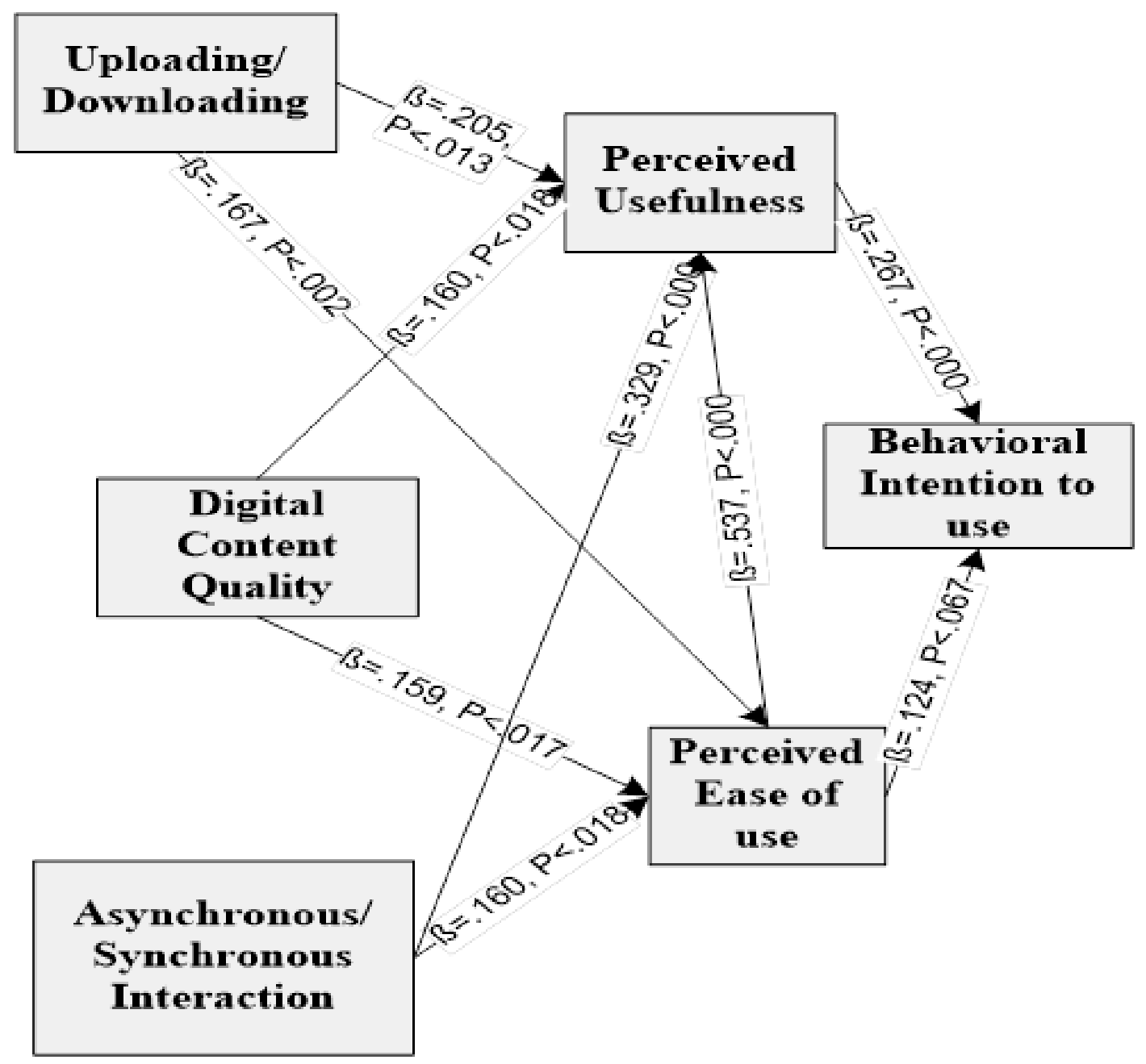

Figure 2: Proposed Model with Hypothesis results

Table 10: Regression Result For H5

\begin{tabular}{|l|l|l|l|l|l|}
\hline H5 & B & $\begin{array}{l}\text { Standard- } \\
\text { Error(B) }\end{array}$ & T & P & $\begin{array}{l}\text { R } \\
\text { Square }\end{array}$ \\
\hline ASI $\rightarrow$ PU & 0.329 & 0.075 & 5.146 & $<0.000$ & 0.108 \\
\hline
\end{tabular}

Table 11: Regression Result For H6

\begin{tabular}{|l|l|l|l|l|l|}
\hline H6 & B & $\begin{array}{l}\text { Standard- } \\
\text { Error(B) }\end{array}$ & P & P & $\begin{array}{l}\text { R } \\
\text { Square }\end{array}$ \\
\hline ASI $\rightarrow$ EOU & 0.160 & 0.074 & 2.393 & $<0.018$ & 0.026 \\
\hline
\end{tabular}

Table 12: Regression Result For H7

\begin{tabular}{|l|l|l|l|l|l|}
\hline H7 & B & $\begin{array}{l}\text { Standard- } \\
\text { Error }(\mathrm{B})\end{array}$ & P & $\begin{array}{l}\text { R } \\
\text { Square }\end{array}$ \\
\hline EOU $\rightarrow$ PU & 0.537 & 0.060 & 9.407 & $<0.000$ & 0.289 \\
\hline
\end{tabular}

Table 13: Regression Result For H8

\begin{tabular}{|l|l|l|l|l|l|}
\hline H8 & B & $\begin{array}{l}\text { Standard- } \\
\text { Error(B) }\end{array}$ & T & P & $\begin{array}{l}\text { R } \\
\text { Square }\end{array}$ \\
\hline PU $\rightarrow$ BI & 0.267 & 0.069 & 4.086 & $<0.000$ & 0.071 \\
\hline
\end{tabular}

Table 14: Regression Result For H9

\begin{tabular}{|l|l|l|l|l|l|}
\hline H9 & B & $\begin{array}{l}\text { Standard- } \\
\text { Error(B) }\end{array}$ & T & P & $\begin{array}{l}\text { R } \\
\text { Square }\end{array}$ \\
\hline EOU $\rightarrow$ BI & 0.124 & 0.075 & 1.840 & $<0.067$ & 0.015 \\
\hline
\end{tabular}

\section{Conclusion}

The global development in the technological era is posing many challenges but at the same time it is opening many avenues of advancements. The distance learning is also affected by the technological developments and shifting towards electronic mode. E-learning is based on online support services, which rely on uploading/downloading of digital contents and interaction through synchronous/asynchronous modes [32]. The role of student support services and its acceptance have become more important [33 - 35]. As in other relevant studies, this study revealed that TAM can effectively be used to predict and understand users' perception on using e-learning support services. 
The results have shown favorable response from the respondents. The hypotheses on "behavioral intention" of using online support service are supported. The results also show that there is a positive readiness for implementation of e-learning systems in Pakistan. The research study shows that high acceptance rate of technology for online teaching and learning can lead to enhance the learning capacity and knowledge level of students. Results also show that uploading and downloading of contents is positively related to "ease of use". The digital content quality has a significant influence on "perceived usefulness". Furthermore, asynchronous and synchronous interaction has a significant influence on "perceived usefulness". The result also elaborate that there is significant influence of "perceived ease of use" on "perceived usefulness" and a significant influence of "ease of use" on "behavioral intention". The students of e-learning have shown positive attitude towards online support services. The "perceived usefulness" has a greater significant correlation with usage behavior than "perceived ease of use". This led to hypothesize that "perceived ease of use" may be a causal predecessor to "perceived usefulness" rather than a direct determinant of technology. Furthermore, this research model may also be applied by other education institutions for evaluating their readiness regarding technology enabled learning.

\section{References}

[1] M. U. Ahmed, N. Sangi and A. Mahmood, "A Learner Model for Adaptable e-Learning", International Journal of Advanced Computer Science and Applications, Vol. 8, No. 6, pp. 139-147, 2017.

[2] A. Klašnja-Milićević, B. Vesin, M. Ivanović, Z. Budimac and L. C. Jain, "Introduction to ELearning Systems", E-Learning Systems. Intelligent Systems Reference Library, Springer, Vol. 112, pp. 3-17, 2017.

[3] C. J. Bonk, M. M. Lee, X. Kou, S. Xu and F. R. Sheu, "Understanding the self-directed online learning preferences, goals, achievements, and challenges of MIT OpenCourseWare subscribers", Journal of Educational Technology \& Society, Vol. 18, No. 2, pp. 349, 2015.

[4] S. Farid, R. Ahmad and M. Alam, "A Hierarchical Model for E-Learning Implementation Challenges using AHP", Malaysian Journal of Computer Science, Vol. 28, No. 3, 2015.

[5] F. Z. Díaz, M. A. Schiavoni, M. A. Osorio, A. P. Amadeo and M. E. Charnelli, "Integrating a learning management system with a student assignments digital repository: a case study", International Journal of Continuing Engineering Education and Life Long Learning, Vol. 25, No. 2, pp. 138-150, 2015.
[6] S. Hrastinski, "Asynchronous and synchronous elearning", Educause quarterly, Vol. 31, No. 4, pp. 51-55, 2008

[7] L. PC, "The Literature Review of Technology Adoption Models And Theories For The Novelty Technology", Journal of Information Systems and Technology Management, Vol. 14, No. 1, pp. 21-38, 2017.

[8] F. Davis, A technology acceptance model for empirically testing new end- user information systems: Theory and results (Doctoral dissertation). Massachusetts Institute of Technology, Massachusetts, USA, 1986.

[9] F. D. Davis, "Perceived usefulness, perceived ease of use, and user acceptance of information technology", MIS Quarterly, Vol. 13, No. 3, pp. 319-339, 1989.

[10] M. S. A. El-Seoud and I. A. Taj-Eddin, N. Seddiek, M. M. El-Khouly, and A. Nosseir, "E-Learning and students' motivation: A research study on the effect of e-learning on higher education" International Journal of Emerging Technologies in Learning (IJET), Vol. 9, No. 4, pp. 20-26, 2014.

[11] R. G. Saadé and D. Kira, "Computer anxiety in e-learning: The effect of computer self-efficacy", Journal of Information Technology Education, Vol. 8, 2009.

[12] F. Kanwal and M. Rehman, "Factors Affecting E-Learning Adoption in Developing Countries-Empirical Evidence from Pakistan's Higher Education Sector", IEEE Access, Vol. 5, pp. 10968-10978, 2017.

[13] K. Maina and D. M. Nzuki, "Adoption Determinants of E-learning Management System in Institutions of Higher Learning in Kenya: A Case of Selected Universities in Nairobi Metropolitan", International Journal of Business and Social Science, Vol. 6, No. 2, 2015.

[14] S. Y. Park, "An Analysis of the Technology Acceptance Model in Understanding University Students' Behavioural Intention to Use e-Learning", Educational Technology \& Society, Vol. 12, No. 3, pp. 150-162. 2009.

[15] U. T. P. Maldonado, G. F. Khan, J. Moon and J. J. Rho, "E-learning motivation and educational portal acceptance in developing countries", Online Information Review, Vol. 35, No. 1, pp. 66-85, 2011.

[16] C. Nanayakkara, "A model of user acceptance of learning management systems: a study within tertiary institutions in New Zealand", International Journal of Learning, Vol. 13, No. 12, pp. 223, 2007.

[17] Z. Hussein, "Leading to Intention: The Role of Attitude in Relation to Technology Acceptance Model in E-Learning", Procedia Computer Science, Vol. 105, pp. 159-164, 2017. 
[18] N. Marangunic, and A. Granic, "Technology acceptance model: a literature review from 1986 to 2013", University Access Information Society, pp. 81-95, 2015

[19] W. M. Al-Rahmi, and A. M. Zeki, "A model of using social media for collaborative learning to enhance learners' performance on learning", Journal of King Saud University-Computer and Information Sciences, Vol. 29, No. 4, pp. 526-535, 2017.

[20] W. M. Al-Rahmi, N. Alias, M. S. Othman, I. A Ahmed, A. M. Zeki, and A. Saged, "Social media use, collaborative learning and students'academic performance: a systematic literature review of theoretical models", Journal of theoretical \& applied information technology, Vol. 95, No. 20, 2017.

[21] Teo, S.H. Thomson, V.K.G. Lim and R.Y.C. Lai, "Intrinsic and Extrinsic Motivation in Internet Usage", Omega , Vol. 27, No. 1, pp. 25-37, 1999

[22] T. Teo, and P. Schalk, "Understanding technology acceptance in pre-service teachers: A structuralequation modelling approach", The Asia-Pacific Education Researcher, Vol. 18, No. 1, pp. 47-66, 2009 .

[23] N. A. Sangi, "Access Strategy for Blended Elearning: An AIOU Case Study", Editor Managing Editor, Vol. 5, No. 2, 2009

[24] A. Al-Adwan, A. Al-Adwan, and J. Smedley, "Exploring students acceptance of e-learning using Technology Acceptance Model in Jordanian universities", International Journal of Education and Development using Information and Communication Technology, Vol. 9, No. 2, pp. 4, 2013.

[25] T. Farahat, "Applying the technology acceptance model to online learning in the Egyptian universities", Procedia-Social and Behavioral Sciences, Vol. 64, pp. 95-104, 2012

[26] P. A. Ratna, and S. Mehra, "Exploring the acceptance for e-learning using technology acceptance model among university students in India", International Journal of Process Management and Benchmarking, Vol. 5, No. 2, pp. 194-210, 2015.
[27] M. Masrom, "Technology acceptance model and e-learning", Technology, Vol. 21, No. 24, pp. 81, 2007.

[28] J. F. Hair, W. C. Black, B. J. Babin, and R. E. Anderson, "Multivariate Data Analysis", Vectors, p. $816,2010$.

[29] N. Chintalapati and V.S.K. Daruri, "Examining the Use of YouTube as a Learning resource in higher education: Scale development and Validation of TAM model", Telematics and Informatics,(2016), Available: doi:http://dx.doi.org/10.1016/j.tele.2016.08.008

[30] S. Taylor and P. Todd, "understanding information technology usage: a test of competing models", information Systems Research, Vol. 6, pp. 144-76, 1995

[31] R. H. Shroff, C. C. Deneen and D.M. Ng, "Analysis of the technology acceptance model in examining students' behavioural intention to use an eportfolio system", Australasian Journal of Educational Technology, Vol. 27 No. 4, pp. 600-618, 2011.

[32] M. Butorac, Z. Nebic, D. Nemcanin and N. Rončević, "Blended E-learning in Higher Education: Research on Students' Perspective", Issues in Information Science and information Technology, Vol. 8, pp.409-429, 2001.

[33] N. Asabere and S. Enguah, "Use of Information \& Communication Technology (ICT) in Tertiary Education in Ghana: A Case Study of Electronic Learning (E-learning)", International Journal of Information and Communication Technology Research, Vol. 2, No. 1, pp.62-68, 2012.

[34] K. Cheung, O. Lee, and Z. Chen, "Acceptance of Internet-based learning medium: the role of extrinsic and intrinsic motivation", Information \& Management, Vol. 42, pp. 1095-1104, 2005.

[35] R. Saade, F. Nebebe, and W. Tan, "Viability of the "Technology Acceptance Model" in Multimedia Learning Environments: A Comparative Study", Interdisciplinary Journal of Knowledge and Learning Objects, Vol. 3, pp.175-184, 2007. 